\title{
Global mapping of maximum emission heights and resulting vertical profiles of wildfire emissions
}

\author{
M. Sofiev ${ }^{1}$, R. Vankevich ${ }^{2,3}$, T. Ermakova ${ }^{2}$, and J. Hakkarainen ${ }^{1,4}$ \\ ${ }^{1}$ Finnish Meteorological Institute, Helsinki, Finland \\ ${ }^{2}$ Russian State Hydrometeorological University, St. Petersburg, Russia \\ ${ }^{3}$ St.Petersburg Research Centre for Environmental Safety, St. Petersburg, Russia \\ ${ }^{4}$ Lappeenranta University of Technology, Lappeenranta, Finland
}

Correspondence to: M. Sofiev (mikhail.sofiev@fmi.fi)

Received: 9 July 2012 - Published in Atmos. Chem. Phys. Discuss.: 2 August 2012

Revised: 8 May 2013 - Accepted: 10 June 2013 - Published: 24 July 2013

\begin{abstract}
The problem of characteristic vertical profile of smoke released from wildland fires is considered. A methodology for bottom-up evaluation of this profile is suggested and a corresponding global dataset is calculated. The profile estimation is based on: (i) a semi-empirical formula for plume-top height recently suggested by the authors, (ii) satellite observations of active wildland fires, and (iii) meteorological conditions evaluated for each fire using output of the numerical weather prediction model. Injection profiles of the plumes from all fires recorded globally from March 2000 till November 2012 are estimated with a time step of $1 \mathrm{~h}$. The resulting 4-dimensional dataset is split into daytime and nighttime subsets. The subsets are projected onto a global grid with a resolution of $1^{\circ} \times 1^{\circ} \times 500 \mathrm{~m}$, aggregated to a monthly level, and normalised by total emissions in each vertical column. Evaluation of the obtained dataset was performed in several ways. Firstly, the quality of the semiempirical formula for plume-top computations was evaluated using updated MISR fire Plume Height Project data. Secondly, the upper percentiles of the profiles are compared with an independent dataset of space lidar CALIOP. Thirdly, the results are compared with the distribution suggested for AEROCOM modelling community. Finally, the inter-annual variations of the calculated profiles are estimated.
\end{abstract}

\section{Introduction}

Wildland fires are one of the major contributors of trace gases and aerosols to the atmosphere. The fire smoke affects chemical and physical properties of the atmosphere at a wide range of spatial and temporal scales, which are directly related to the atmospheric lifetime of the released pollutants. In turn, the species lifetime is determined by the removal and chemical transformations processes, which strongly depend on altitude. The bulk of the fire smoke is released in the atmospheric boundary layer (ABL) (Sofiev et al., 2009, 2012; Val Martin et al., 2010) but strong fires occurring under favourable atmospheric conditions, such as deep convection or vertical updrafts related to frontal zones, can send the plumes high into the free troposphere (FT) (Freitas et al., 2007; Labonne et al., 2007) and up to the stratosphere, where the smoke can stay for a long time and spread over very wide areas (Dirksen et al., 2009; Fromm et al., 2000; Luderer et al., 2006). Therefore, it is of crucial importance, for both climate and atmospheric composition applications, to reproduce the vertical distribution of the fire plumes.

Most atmospheric composition models distribute the fire emissions homogeneously from the ground up to a prescribed plume-top height $H_{\mathrm{p}}$, which is sometimes regiondependent. For global chemistry transport models, Davison (2004), Forster et al. (2001), and Liousse et al. (1996) set it to about $2 \mathrm{~km}$, whereas for regional simulations of smoke from intense Canadian fires Westphal and Toon (1991) used 5$8 \mathrm{~km}$. Lavoué et al. (2000) used $H_{\mathrm{p}}$ of about $2-3 \mathrm{~km}$ for fires in the northern latitudes, but assumed $7-8 \mathrm{~km}$ for powerful 
crown fires independently from meteorological conditions. For central America, an $H_{\mathrm{p}}$ of $\sim 0.9-1.5 \mathrm{~km}$ was suggested by Kaufman et al. (2003). Based on this estimation, Wang et al. (2006) used $1.2 \mathrm{~km}$ (8th model layer) in mesoscale simulations and conducted sensitivity studies, showing $15 \%$ variation of the near-surface concentrations if $H_{\mathrm{p}}$ is varied plusor-minus one model layer (a few hundreds of metres).

Well-known formulas of Briggs (1975) are applied in the Fire Emission Production Simulator (FEPS, http://www.fs. fed.us/pnw/fera/feps/index.shtml), which complements them with a comprehensive fire description. However, evaluation of the system performance against MISR by Raffuse et al. (2012) confirmed limited applicability of Briggs formulations to wildland fires, in agreement with conclusions of Sofiev et al. (2012). An evaluation and some improvements of the technique were suggested by Stein et al. (2009) based on dispersion modelling of a few plumes.

More accurate approaches for the fire injection height computations, suggested by e.g. Freitas et al. (2007), Lavoué et al. (2000), Rio et al. (2010) and Sofiev et al. (2012), are based on explicit accounting for features of individual fires and, except for Lavoué et al. (2000), actual ambient atmospheric conditions. These methods represent the plume vertical distribution better than the above-mentioned simple approaches but require quite detailed information on each fire (at least its strength at each specific time). This information is not available if the emission estimates are based on burntarea data or are aggregated in time and space (e.g. the widely used Global Fire Emission Dataset GFED (Van der Werf et al., 2006) or similar-type inventories). Therefore, there is a need for pre-calculated typical injection profiles of wildland fires emissions, which can be used in practical applications if the detailed fire information is not available or its usage is unfeasible from a computational standpoint.

An estimation of typical injection height from fires for North America was performed by Val Martin et al. (2010) using MISR plume height observations. In that work, the authors evaluated the inter-annual variability, relation to vegetation type, as well as seasonal variations of the smoke injection height, using statistics from about 3300 plumes. Characteristic injection heights and smoke distribution were estimated for Indonesian fires by Tosca et al. (2011) using MISR and CALIOP observations over 2001-2009. Finally, Dentener et al. (2006) suggested a single global map of the injection top height but did not specify the underlying data and analysis procedures.

The goals of the current work are: (i) to estimate the characteristic injection of vertical profiles of wildland fire plumes over the globe, (ii) to determine their diurnal and seasonal variations, and (iii) to explore peculiarities of their spatial patterns.

In the following Sect. 2 we outline the methodology, formalise the problem and describe the input datasets. Section 3 describes the preparatory steps and additional evaluation of the methodologies involved. Section 4 presents the outcome of the calculations and Sect. 5 compares the results with other datasets and discusses some features of the obtained profiles.

\section{Materials and methods}

\subsection{Calculation of the top height of fire emission plumes}

Calculation of characteristic injection profile is based on a recently suggested semi-empirical formula for the fire-plume top height (Sofiev et al., 2012). According to this methodology, the plume top $H_{\mathrm{p}}$ depends on the fire radiative power FRP, ABL height $H_{\mathrm{abl}}$, and Brunt-Väisälä frequency in the free troposphere $N_{\mathrm{FT}}$ :

$H_{\mathrm{p}}=\alpha H_{\mathrm{abl}}+\beta\left(\frac{\mathrm{FRP}}{P_{f 0}}\right)^{\gamma} \exp \left(-\delta N_{\mathrm{FT}}^{2} / N_{0}^{2}\right)$.

The values for coefficients $\alpha, \beta, \gamma$, and $\delta$, and normalising constants $P_{f 0}$ and $\mathrm{N}_{0}$ are: $\alpha=0.24 ; \beta=170 \mathrm{~m} ; \gamma=$ $0.35 ; \quad \delta=0.6, \quad P_{f 0}=10^{6} \mathrm{~W}$, and $N_{0}^{2}=2.5 \times 10^{-4} \mathrm{~s}^{-2}$. These coefficients have been obtained from calibration of the formula (1) using MISR fire plume observations. As discussed by Sofiev et al. (2012), this approach has both strong and weak points. In particular, the MISR dataset available for the development did not cover all relevant types of vegetation and regions of the globe. Also, the number of considered events was comparatively limited. The strongest point of this methodology is that the application of the formula requires just a few basic meteorological and fire characteristics, which have been available globally for more than a decade.

\subsection{Input data for the computations}

\subsubsection{Fire intensity data}

The fire radiative power data are obtained from the activefire observations by Moderate Resolution Imaging Spectroradiometer (MODIS) instrument onboard Aqua and Terra satellites (http://modis.gsfc.nasa.gov, Justice et al., 2002; Kaufman et al., 1998). This dataset is the only existing collection that covers the whole globe over more than a decade and provides FRP and other characteristics of active fires. The MODIS Terra subset is available starting from March 2000 (first data already came in February), Aqua was launched in 2002. We used all level-2 data from Collection 5 of both instruments, starting from their first day to November 2012.

The data are available as a series of granules, each corresponding to $5 \mathrm{~min}$ of the satellite retrievals. Inside the granule, the pixel size varies from $1.01 \mathrm{~km}^{2}$ up to $9.74 \mathrm{~km}^{2}$ depending on the viewing angle. MODIS typically has 2-4 overpasses per day over each specific region of the globe.

FRP products have also recently become available from geostationary satellites, such as the Spinning Enhanced Visible and Infrared Imager SEVIRI onboard the Meteosat MSG 
satellite (Kaiser et al., 2009; Roberts and Wooster, 2008). Large pixel sizes of such satellites (more than $10 \times 10 \mathrm{~km}^{2}$ ) preclude their direct utilisation since such pixels often cover many individual fires. Secondly, SEVIRI has limited domain: a circle with radius of about 60 degrees, which covers Africa, Europe except northern Europe, limited areas in Asia and South America. However, high temporal resolution (15 min) makes SEVIRI a valuable source of information about temporal evolution of the fire intensity.

\subsubsection{Meteorological parameters}

The meteorological information over the globe is taken from the operational archives of the Integrated Forecasting System (IFS) of the European Centre for Medium-Range Weather Forecast (ECMWF, http://www.ecmwf.int). The data have been retrieved with a horizontal resolution of $1^{\circ} \times 1^{\circ}$ for all years. Vertical resolution varied: in 2006, the ECMWF model was switched from 61 to 91 non-equidistant hybrid levels. These roughly correspond to 40 and 60 levels between the surface and the tropopause, respectively.

The Brunt-Väisälä frequency was computed straightforwardly from vertical temperature profiles. ABL height was estimated by the combination of dry-parcel and criticalRichardson-number methods, whose performance was evaluated by Sofiev et al. (2006) and Fisher et al. (1998) and recently advanced by Kouznetsov et al. (2012). The procedure thus accounts for both main mechanisms of ABL formation: mechanical by wind shear and thermal by convection. The depth of the mechanically induced ABL is determined as a height where the bulk Richardson number exceeds the critical value of $\sim 0.25$. The dry-parcel method determines the convective-ABL top as the height where the temperature of an adiabatically rising dry parcel becomes equal to the ambient level (at the surface the parcel is attributed with some temperature excess that depends on near-surface stratification). The highest of the two values is taken as the ABL top height estimate.

\subsubsection{Plume height and profile observations}

This study does not aim to review the plume-top formula (1) but, since this is the first global application of the methodology, its initial evaluation by Sofiev et al. (2012) was extended using the updated dataset of MISR Plume Height Project (Kahn et al., 2008; Mazzoni et al., 2007). We took all information available to date, which includes injection heights for about 2500 fires that occurred in the US, Canada, Siberia, Africa, and Borneo, from 2005 to 2009 as isolated series of events. Among the quantities available for each plume, we selected the "best top height", which corresponds to the maximum wind-corrected and errorfiltered plume elevation (see http://misr.jpl.nasa.gov/getData/ accessData/MisrMinxPlumes/productLabeling/ for details).
Data for direct evaluation of the obtained mean vertical profiles were taken from the dataset of Cloud-Aerosol Lidar with Orthogonal Polarization (CALIOP) onboard the NASA CALIPSO satellite (CALIPSO, 2011). The dataset contains level-3 global monthly mean profiles of the aerosol extinction coefficient and optical depth derived from the qualityscreened CALIOP level 2 aerosol profiles (Vaughan et al., 2009). The data are projected to a global grid, extending vertically up to $12 \mathrm{~km}$ with a resolution of $5^{\circ} \times 2^{\circ} \times 60 \mathrm{~m}$. Covered period is 2006-2012. The dataset includes a rough attribution of the observed aerosols. For the comparison, we picked only layers with a smoke fraction $>0.9$ and calculated the height of the 90th percentile of the total aerosol amount in the column (assumed proportional to aerosol optical thickness).

\subsection{Computation of mean vertical profile of fire emission}

The target quantity of the study is the monthly gridded normalised vertical distributions of the fire emission for day and night:

$$
\begin{aligned}
& e(i, j, k, m, d), i=\overline{1, I}, j=\overline{1, J}, k=\overline{1, K} \\
& m=\overline{1,12}, d \in[\text { day,night }], \sum_{k=1}^{K} e(i, j, k, m, d)=1, \forall i, j, m, d
\end{aligned}
$$

where $I, J, K$ are the $x$-, $y$-, and $z$-wise dimensions of the grid, $i, j, k$ are corresponding indices, $m$ is month number, and $d$ is a day- or nighttime indicator.

From a physical standpoint, the quantity $e(i, j, k, m, d)$ is a mean fraction of fire emission in the grid cell $(i, j)$ injected into the layer $k$ in month $m$ during the day or night (index $d$ ).

The mean emission distribution (Eq. 2) is obtained by summing-up the plumes from individual fires. For each fire, we assumed one-day persistence, i.e. the fire was assumed to start at 00:00 local time of the day of the observation and end at 24:00 of the same day. During these $24 \mathrm{~h}$, the FRP was assumed to vary according to the mean FRP diurnal variation derived from SEVIRI (discussed in the next section). The resulting set of 24 hourly emission fluxes was combined with meteorological data and treated with the formula (1), resulting in 241 -D vertical smoke plumes. These were projected to a global grid with the cell size of $1^{\circ} \times 1^{\circ} \times 500 \mathrm{~m} \times 1 \mathrm{~h}$. The obtained gridded dataset was split into 12 monthly subsets (all years together) and then to day- and nighttime subsubsets. Finally, emission in each of the 24 sub-subsets was summed up and every vertical column was normalised to obtain the relative injection profiles.

The procedure involves several assumptions. Firstly, following Briggs (1975), the fire plume thickness is taken equal to the height of its centreline $H_{\mathrm{C}}$, so that the plume top $H_{\mathrm{p}}=1.5 H_{\mathrm{C}}$. Distribution of the emitted masses is taken uniform inside each plume from $H_{\mathrm{p}} / 3$ up to $H_{\mathrm{p}}$. Secondly, a relation between FRP [W] and total emission rate $E\left[\mathrm{~kg} \mathrm{~s}^{-1}\right]$ 
is assumed to be linear following Kaufman et al. (1998), Sukhinin et al. (2005), Wooster et al. (2005), Freeborn et al. (2008), Sofiev et al. (2009), and Kaiser et al. (2012). Thirdly, the profiles are calculated for total fire emission, i.e. a sum of all species released from the fire. Owing to the linearity assumption for total emission, the normalised emission distribution (2) is independent from the emission factor and can be computed for FRP (i.e., taking a unit emission factor).

Among the above assumptions, a plume thickness numerically equal to the position of its centreline is probably the easiest to challenge. However, after experimenting with several distributions, we found that the sensitivity of the averaged profiles to those of individual fires is low: the differences are averaged out. Therefore, we stick to the suggestion of Briggs as the simplest to implement.

The calculations performed for the total emission lead to uncertainties when the profiles are applied to individual species released by fires. The emission factors depend on features of underlying vegetation and fire. For instance, poor ventilation is usually associated with increased emission of $\mathrm{CO}$ and aerosols but also with moderate thermal energy release and low smoke injection. Therefore, bulk-emission profiles computed in this study should be considered as only the first step towards comprehensive emission injection computations, which will take these dependencies into account.

\section{Preparatory steps for the profile calculations}

Before starting the computations, several preparations were made: (i) additional evaluation of the plume-rise formula, (ii) determination of mean diurnal variation of the fire intensity, and (iii) selection of the method for filling in the gaps in the obtained dataset.

\subsection{Global evaluation of the plume rise formula}

The plume-top formulation (1) has been evaluated by Sofiev et al. (2012) for boreal and mid-latitude fires, which is insufficient for global application. Therefore, additional evaluation was performed using the recent additions to MISR Plume Height dataset. These include fires in Africa and Borneo, which allowed extending the original evaluation towards savannah and tropical forests.

We considered only so-called "good" plume height retrievals, for which the accuracy of the MISR plume-top retrieval is the highest (Nelson et al., 2008; Val Martin et al., 2010). This selection reduces the size of the dataset from about 2500 fire cases down to 1650 cases, which is sufficient for the evaluation task.

The comparison of predictions of the formula (1) with MISR observations (Fig. 1) confirms (and strengthens) the main conclusion of the original evaluation by Sofiev et al. (2012). Formulation (1) proved to be robust and capable of at least $70 \%$ of predictions within $500 \mathrm{~m}$ of the ob- servations (which is the accuracy of the MISR estimations themselves) in all conditions from boreal forests to tropical savannas. For Borneo, the fraction of good predictions was even higher at $94 \%$. The formula performance is further discussed in Sect. 5.

\subsection{Diurnal cycle of fire intensity}

During the night, both fire intensity and turbulent mixing are suppressed, which leads to a reduction of the number of active fires $N_{\text {fires }}$ and mean FRP per active fire $\left(\mathrm{FRP}_{\text {per-fire }}\right.$; Giglio, 2007; Roberts et al., 2009). The total regional energy release, $\mathrm{FRP}_{\text {total }}=N_{\text {fires }} \times \mathrm{FRP}_{\text {per-fire, }}$, decreases even stronger, which corresponds to low nighttime emission. However, it is the diurnal cycle of FRP per-fire that drives the variation of the injection height. Reduction of $\mathrm{FRP}_{\text {per-fire }}$ correlates with the nighttime stable atmospheric stratification and the low ABL height, leading to strong reduction of the injection height.

Among the three above-mentioned fire-related quantities, only $\mathrm{FRP}_{\text {total }}$ is observed by the satellites. Limited spatial resolution of even low-orbit (LEO) satellites (MODIS resolution is $1-3 \mathrm{~km}$ ), precludes them from seeing individual fires. For geostationary orbiting (GEO) instruments, such as SEVIRI, resolution is even worse: $10-30 \mathrm{~km}$. Therefore, quantities actually measured from space are the number of overheated pixels ( $\left.N_{\text {fire-pixels }}\right)$ and mean FRP of such pixels (FRP per-pixel $_{\text {) }}$, and their relations with $N_{\text {fire }}$ and FRP $\mathrm{Fer-fire}$ are not fully established. Such aggregation is not the primary concern for the absolute emission fluxes, which are usually assumed to be linear to FRP, but it is a challenge for injection height calculations, where the dependence is non-linear.

Within this study, we do not aim to resolve the above uncertainty. Instead, we derive practically applicable estimates of diurnal cycles for both $\mathrm{FRP}_{\text {total }}$ and $\mathrm{FRP}_{\text {per-fire, which }}$ would be compatible with MODIS active-fire observations.

Estimating the diurnal cycles directly from MODIS FRP data is feasible only for high latitudes (Vermote et al., 2009). The typical four overpasses per day at low- and mid-latitudes, even if not obscured by clouds, are not sufficient to resolve the fire cycle (Ichoku et al., 2008). The only LEO satellite, which has more than 10 overpasses per day over equatorial regions, is TRMM with Visible and Infrared Scanner VIRS onboard. It provides only active-fire counts and thus can be used to estimate the diurnal cycle of $N_{\text {fire-LEO-pixels, }}$ which is the closest available analogy to $N_{\text {fires }}$. Such an analysis has been reported by Giglio (2007).

The GEO instrument SEVIRI has sufficiently high temporal resolution $(\sim 15 \mathrm{~min})$ and has been used to estimate the diurnal variations of $\mathrm{FRP}_{\text {total }}$ and $\mathrm{FRP}_{\text {per-GEO-pixel }}$ (Roberts and Wooster, 2008; Roberts et al., 2009).

Comparing the above-quoted results for SEVIRI and VIRS, we concluded that derivation of diurnal cycle of $\mathrm{FRP}_{\text {per-LEO-pixel }}$ (the closest available analogy of FRP $\mathrm{Fer}_{\text {-fire }}$ ) for LEO satellite is beyond reach: the uncertainties and 


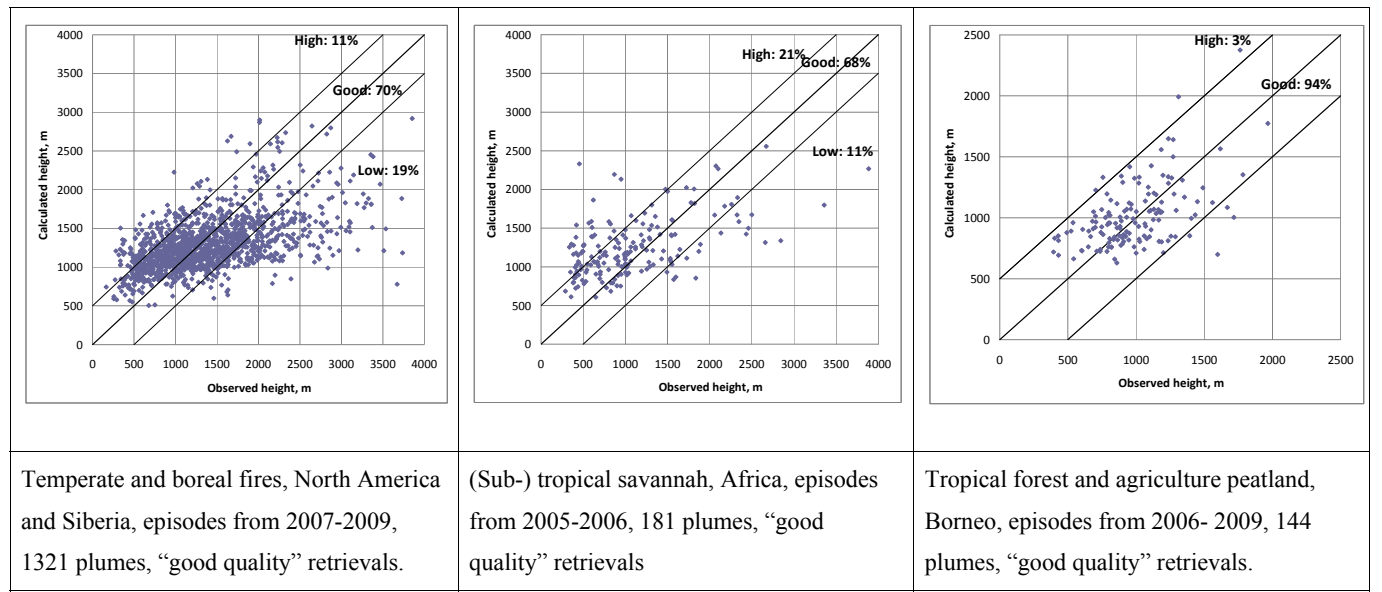

Fig. 1. Global evaluation of plume-top formulations of Sofiev et al. (2012) against MISR data. Unit $=[\mathrm{m}]$.

scatter in the data are too high. However, the dynamic range of the variation of $N_{\text {fire-LEO-pixel }}$ reported for VIRS by Giglio

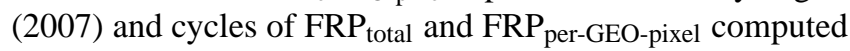
for SEVIRI by Roberts et al. (2009) and Vermote et al. (2009) appeared compatible, thus suggesting that SEVIRI-based variations of $\mathrm{FRP}_{\text {total }} \mathrm{FRP}_{\text {per-GEO-pixel }}$ are sufficient for the present study.

Since the above works included only qualitative presentations of the variations, we had to recompute them. Calculations were made using SEVIRI data for a complete year, 2010, for three different land-use types: forest, grass, and mixed (compiled based on land-use maps of the US Geological Survey, USGS). The normalised diurnal variations $M_{\text {total }}$ and $M_{\text {per-GEO-pixel }}$ for FRP total $_{\text {and }}$ FRP per-GEO-pixel were modelled using truncated Fourier series with the coefficients $a_{k}, b_{k}$ fit into SEVIRI total and per-pixel FRP data over the whole observed domain, separately for different land use types $l$ :

$$
\begin{aligned}
& M_{\bullet}\left(n_{t}, l\right)=a_{0}^{\bullet}+\sum_{k=1}^{3} a_{k}^{\bullet}(l) \cdot \cos \left(\frac{k}{12} \pi n_{t}\right)+\sum_{k=1}^{3} b_{k}^{\bullet}(l) \\
& \cdot \sin \left(\frac{k}{12} \pi n_{t}\right)
\end{aligned}
$$

Here, $n_{t}$ is an hour of the day, $l$ is a land-use type, sign "•" denotes "total" or "per-GEO-pixel" labels, and the Fourier coefficients $a_{k}, b_{k}$ are obtained by fitting this model to the SEVIRI FRP data. The obtained Fourier coefficients are presented in Table 1 and the diurnal cycles are shown in Fig. 2.

As seen from Fig. 2, the diurnal cycle of $\mathrm{FRP}_{\text {total }}$ is a single-peak curve, the dynamic range of which exceeds a factor of 20. In contrast, FRP per-GEO-pixel $_{\text {exhibits several ups }}$ and downs with a very modest range of variation - a factor of 2 . The small peaks in the morning and in the evening, as well as the local minima next to them, are not the artefacts of the Fourier processing but seem to represent the varying number of fires. Indeed, when fires are just starting in the morning or dying out in the evening, the mean $\mathrm{FRP}_{\text {per-pixel }}$ is small, which corresponds to the minima around 08:00 and 17:00 LT. But when the daytime fires are out, the number of fires reduces with only powerful events, which survive through night, remain visible for the satellite. Then the mean FRP $_{\text {per-GEO-pixel increases again. }}$

In the computations, we used the $\mathrm{FRP}_{\text {total }}$ diurnal cycle to simulate the variation of bulk-emission fluxes, whereas the FRP $_{\text {per-GEO-pixel }}$ cycle is used for the injection height. Each of the three land-use types was considered separately.

\subsection{Gap filling}

Apart from regions with regular fire events, there are many areas where few or no fires took place during some months of the analysed 12 years (Fig. 3). This leads to patchiness of the maps, which is inconvenient from a practical standpoint: some emission inventories are based on modelled fire probability or external fire inventories, which are not constrained with fires registered by MODIS. Therefore, a gap-filling procedure was applied to the cells, which had no fires reported for the specific month but had at least 3 out of 8 neighbouring cells with valid profiles: $N_{\text {valid }} \geq 3$. Then the profile in the empty cell $\left(i_{\mathrm{e}}, j_{\mathrm{e}}\right)$ for the month $m_{\mathrm{e}}$ is computed as a linear combination of the valid neighbouring ones $\left(i_{\mathrm{n}}, j_{\mathrm{n}}\right)$, weighted with the number of fires $N_{\mathrm{fn}}$ in each of them:

$e\left(i_{\mathrm{e}}, j_{\mathrm{e}}, k, m_{\mathrm{e}}, d\right)=\frac{\sum_{n=1}^{N_{\text {valid }}} e\left(i_{\mathrm{n}}, j_{\mathrm{n}}, k, m_{\mathrm{e}}, d\right) N_{\mathrm{fn}}\left(i_{\mathrm{n}}, j_{\mathrm{n}}, m_{\mathrm{e}}\right)}{\sum_{n=1}^{N_{\text {valid }}} N_{\mathrm{fn}}\left(i_{\mathrm{n}}, j_{\mathrm{n}}, m_{\mathrm{e}}\right)}$,

$k=\overline{1, K}$

This procedure does not extrapolate the profiles far outside the observed areas, rather filling in the holes between the grid cells with valid data. In the following sections, we always use 
Table 1. Fourier coefficients for FRP diurnal variation obtained from spectral analysis of SEVIRI data.

\begin{tabular}{lrrrrrrr}
\hline \multicolumn{2}{c}{$a 0$} & $a 1$ & $a 2$ & $a 3$ & $b 1$ & $b 2$ & $b 3$ \\
\hline Total FRP & & & & & & & \\
\hline Grass, 2010 & 1.000 & -0.970 & 0.415 & -0.143 & -0.592 & 0.397 & -0.196 \\
Mixed, 2010 & 1.000 & -1.288 & 0.631 & -0.223 & -0.673 & 0.605 & -0.357 \\
Forest, 2010 & 1.000 & -1.180 & 0.587 & -0.296 & -0.740 & 0.598 & -0.380 \\
\hline Mean FRP per pixel & & & & & & \\
\hline Grass, 2010 & 1.000 & -0.214 & 0.140 & -0.084 & -0.112 & 0.023 & -0.016 \\
Mixed, 2010 & 1.000 & -0.198 & 0.162 & -0.090 & -0.129 & 0.014 & -0.003 \\
Forest, 2010 & 1.000 & -0.041 & 0.141 & -0.145 & -0.119 & 0.037 & -0.021 \\
\hline
\end{tabular}

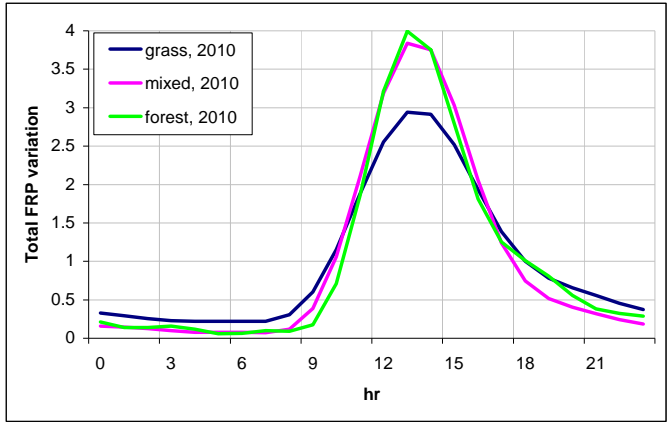

a)

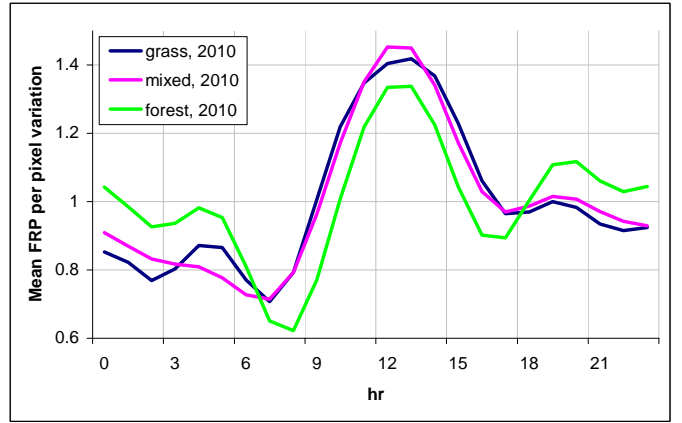

b)

Fig. 2. Diurnal variations of total FRP (left), mean FRP per GEO-pixel (right). SEVIRI, mean over 2010. Relative unit.

the gap-filled maps but both products, with and without gapfilling, are available for the users.

\section{Results}

The results of the computations consist of monthly normalised 3-D distributions of the total fire emission over the globe, separately for day- and nighttime, with and without gap filling (available at http://is4fires.fmi.fi).

A spatial pattern of injection heights appeared to be comparatively homogeneous at a regional level but differences between the regions are large. There were also very strong diurnal and significant seasonal variations (Fig. 4).

The highest plumes are predicted for forested regions of North America (Rocky Mountains), parts of the Middle East to the south of the Caspian Sea, and Australia. During local summer season in these regions, the 90th percentile of a mass injection profile can exceed $3 \mathrm{~km}$ (i.e., $90 \%$ of mass is emitted inside the layer spanning from the surface up to $>3 \mathrm{~km}$ ). Interestingly, these are not the regions where most of fires occur. However, fires in Rocky Mountains, albeit not very frequent, are powerful, thus capable of sending the smoke high. In Australia, the fires are also powerful, whereas the high injection is additionally promoted by deep ABL. Conversely, in the Middle East and Caspian region the reason may be a presence of numerous oil refineries, where powerful and persistent flames are partly misinterpreted as fires (see also discussion in Kaiser et al., 2012).

Regions with moderately high injection are forests in Amazonia and equatorial Africa, as well as grasses in southern Africa and central Eurasia. There, the 90th percentile is generally confined within $2.5 \mathrm{~km}$. This outcome is not very surprising: these are regions known for quite strong fires and deep boundary layers (Ichoku et al., 2008b; van der Werf et al., 2010).

Among the regions with generally low injection, one can mention densely populated regions in all continents. There, the fires are probably better controlled and thus do not reach the strength needed to send the smoke high up into the atmosphere. Interestingly, the infamous extremely high plumes from Siberian and Alaskan fires did not manifest themselves even in 90th percentile map (although these regions are indeed characterised with high smoke injection). They were overshadowed by numerous moderate episodes that are much more frequent and responsible for the bulk of annual emission. The second possible factor is a tendency of formula (1) to understate the elevation of high plumes (Fig. 1).

Seasonal variation of the profiles largely follows the fire season (Fig. 4). In temperate and boreal climates, the highest 

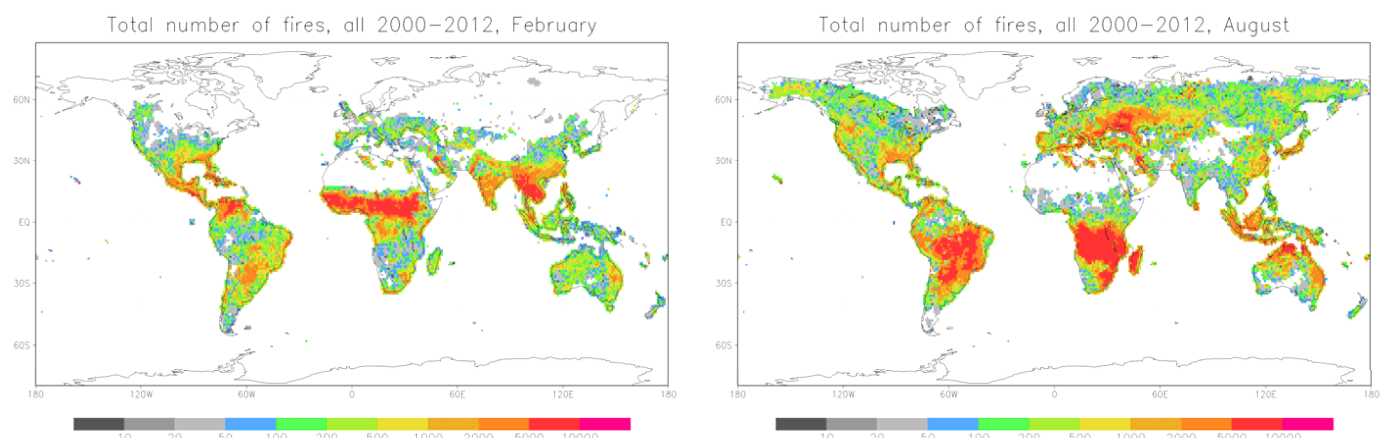

Fig. 3. Number of fires in February (left) and August (right) recorded by MODIS, sum from March 2000 until November 2012.

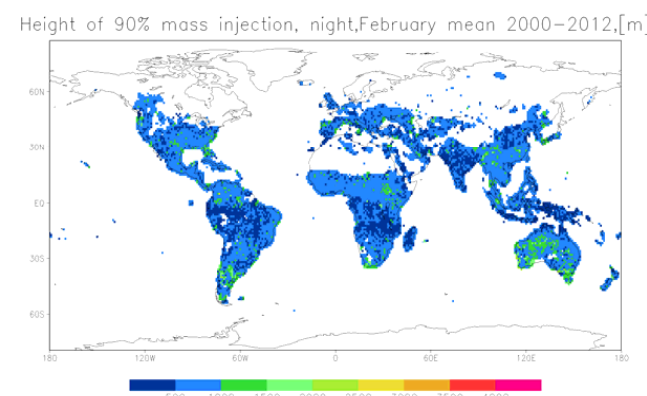

a)

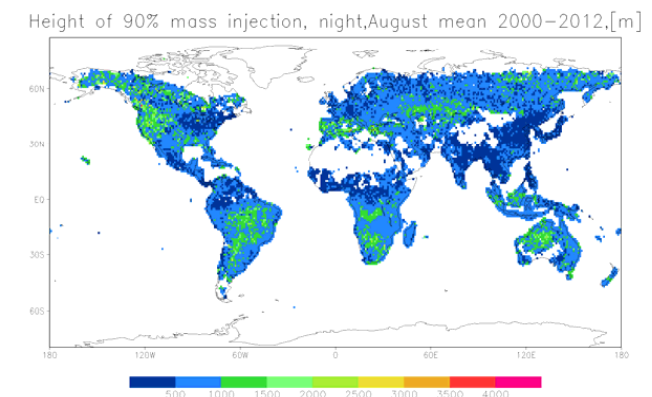

c)

Fig. 4. Injection height for $90 \%$ of mass for night (left) and day (right) for February (top) and August (bottom). Unit $=$ [m].

injections occur during local summer, whereas fires in tropical regions mainly occur during the dry season. In equatorial Africa, it is February to the north of equator and August to the south of it.

In general, the above results agree with common-sense expectations that the strong fires are more probable in the areas with the highest fuel load, strong droughts, and poor forest and fire management. A zonally averaged vertical profile (Fig. 5) shows a similar picture: in the equatorial region, where the bulk of contribution is from comparatively wet equatorial forests (predominantly man-made deforestation fires), the top of the injection profile is lower than in the drier middle latitudes. One can also see that, despite recordhigh fires may reach up to $6 \mathrm{~km}$, they have little impact on

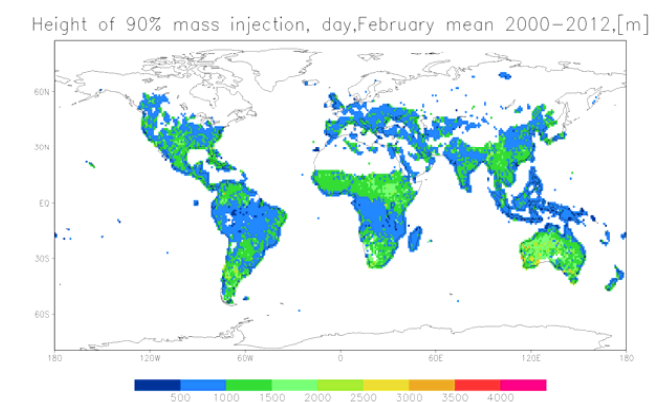

b)

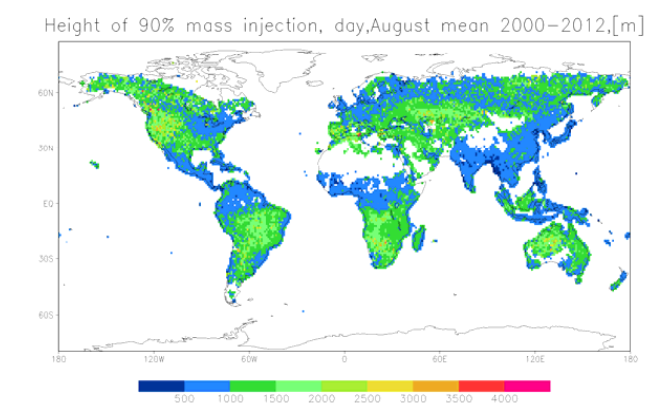

d)

the bulk of the emission: globally, more than $50 \%$ of the fire emission is confined within the lowest $1-2 \mathrm{~km}$, i.e. within the ABL. Both zonal averages and examples for a few regions in Fig. 5 show that the peak of emission during the daytime is attributed to the height range of $500 \mathrm{~m}-1 \mathrm{~km}$, which receives up to $50 \%$ of the total mass. The above-discussed differences in height of the 90th percentile are all due to comparatively limited differences in the mass fraction injected above this layer. This is also consistent with previous estimates (Kahn et al., 2008; Labonne et al., 2007; Sofiev et al., 2009; Val Martin et al., 2010).

Figure 4 and Fig. 5 also demonstrate the impact of diurnal variations of fire intensity and ABL top height. These quantities vary synchronously: small fires and shallow ABLs 

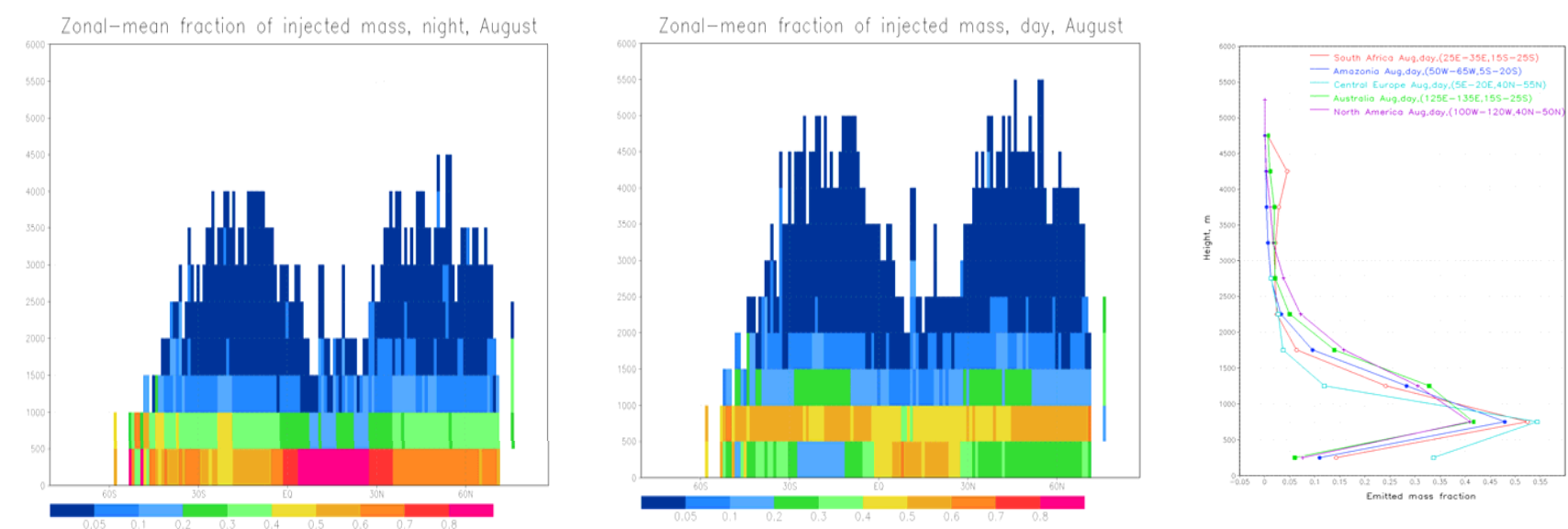

Fig. 5. Mean regional average injection profiles: zonal average during the night, [m] (left), zonal average during the day, [m] (middle), injection profiles for some regions, daytime, August, [mass fraction as a function of $z$ ] (right).

lead to low injection during the night, whereas stronger fires and deeper ABL during the day result in significantly higher injections. As a zonal mean, the bulk of emissions during the night is confined within $500 \mathrm{~m}$, whereas during the day it spreads up to $1.5-2 \mathrm{~km}$.

\section{Discussion}

\subsection{Performance of the plume-top prediction formula}

Evaluation of the plume-top formula (1) reported in Sect. 3.1 has confirmed high accuracy of the approach but also highlighted the tendency of the parameterisation to over-estimate the height of low plumes and under-estimate it for high ones: the predicted heights have a lower dynamic range than the observed ones. For the African dataset this resulted in bias of $\sim 150 \mathrm{~m}$, owing to a significant fraction of over-estimated low plumes $\left(H_{\mathrm{p}}<700 \mathrm{~m}\right)$. For Borneo, where the fires were more powerful (but not too strong) and plumes generally went from $700 \mathrm{~m}$ to $1.5 \mathrm{~km}$, the agreement was very good: the bias was less than $30 \mathrm{~m}$ and $>90 \%$ of the plumes were predicted within $500 \mathrm{~m}$ of the observations. Good agreement was also facilitated by the absence of high plumes, e.g. above $3 \mathrm{~km}$, which are poorly reproduced by our approach (e.g., the left-hand panel for Siberian and US datasets).

A potential explanation of this tendency is missing dependence on the fire area. Thus, grass fires usually occupy wide areas, so that the FRP density, $\left[\mathrm{W} \mathrm{m}^{-2}\right]$, is substantially lower than that for the forest fires, despite the fact that total FRP can be comparable. The present formula does not take this into account due to the high uncertainty of the fire area estimations derived from satellite data and practically unknown fire shape (position of the fire fronts, temperature distribution over the burn area, etc.). As a result, predicted plume top for a wide but low-FRP-density fire will be the same as that for a concentrated limited-area event - provid- ing that the total FRPs and meteorological conditions are the same. In reality, one might expect the plume from a concentrated fire to be injected higher. Similar dependence of the plume injection height on the fire area was noticed by Raffuse et al. (2012), who used the Briggs formula and faced severe difficulties evaluating very wide fires in the northwestern US.

A possible workaround against the under-estimation of high plumes was suggested by Sofiev et al. (2012) in the form of a two-step procedure, which treats free-troposphere plumes separately from those in ABL. Its scores, being extremely good for FT-plumes, however, suffer from misclassification of ABL/FT plume location. Therefore, we did not use it here.

The other uncertainty of the approach is connected with a time period needed for the plume to reach its top position. The formula (1) was calibrated using MISR plume-top data and MODIS FRP for the same fires. Since MISR is onboard the same Terra satellite as MODIS, their observations are performed simultaneously. However, the observed plume was actually formed by the smoke released from the fire some 15-30 min before the overpass (this is a rough estimate of time needed for a fire plume to reach its highest elevation). In the morning and evening hours, it can lead to up to $20-30 \%$ of difference in the FRP value (if estimated from the diurnal variation shown in Fig. 2 and Table 1). Consequently, the height of the plume should also be related to the past-time FRP. It can bring a few tens of metres of difference to the $H_{\mathrm{p}}$ prediction, thus affecting the formula calibration. Finally, the uncertainties of ABL height determination and FRP retrievals also contribute to the gross error.

A specific concern is to what extent the comparison against the existing MISR data qualifies the approach for global application. On the one hand, $\sim 2500$ cases is a thin set, scattered over Eurasia, North America, Africa, and Oceania. Other regions are not covered at all. On the other, if 

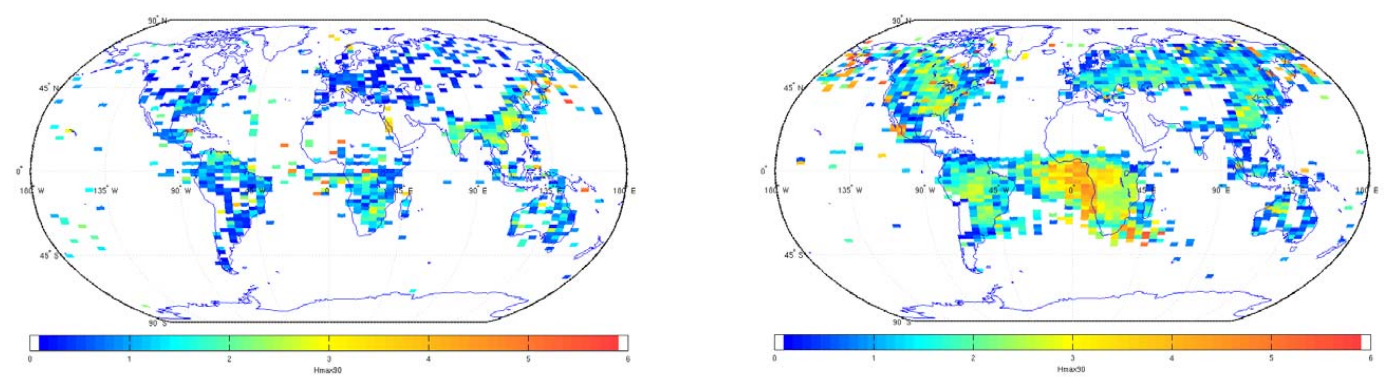

Fig. 6. The 90th percentile of the aerosol profiles observed by the CALIOP lidar, February (left, data 2007-2012) and August (right, data 2006-2012). Daytime. Unit: [km].

one considers physical processes, rather than geographical locations, the dataset is very good and can be considered as representative for global applications. Indeed, in terms of meteorology, a wide range of conditions from strong tropical convection to stable stratification at high latitudes are all represented. With regard to fires, it includes events in dense forests, mixtures of sparse forests and grassland, savannas, and tropical jungles. Sofiev et al. (2009) compared the distribution of FRP for fires, the plumes of which were analysed by MISR, with the full set of MODIS. They found that the MISR dataset includes a somewhat larger fraction of strong fires but still covers practically the whole range of the fire intensity observed by MODIS. Probably the only missing component is huge fires with extremely high energy release, where pyroconvection is the primary factor controlling the plume rise. For such events, formula (1) should be applied with great care or replaced with explicit modelling of dynamics of the highly buoyant plumes.

\subsection{Comparison of profiles with CALIOP observations}

The CALIOP monthly vertical profiles of aerosols (CALIPSO, 2011), presently covering the period 20062012, provide arguably the only reference dataset for evaluation of mean fire injection heights. However, direct comparison between the profiles obtained in the current work and the CALIOP observations is not possible because (i) CALIOP observes less than $3 \%$ of the Earth's surface and its overpasses are infrequent, (ii) it cannot distinguish between fresh and aged plumes, (iii) the detection of aerosol type is not accurate and, (iv) in particular, it assumes that only elevated aerosol clouds can be the fire smoke (Omar et al., 2009). One of the consequences of these issues is that the mean fire-attributed plumes are "shifted" upwards due to the cut-off of their lower parts. However, the upper percentiles of injection height can still be compared over regions with widespread fires: they are not too sensitive to the cut-off of the low plumes.

Comparison of the 90th percentile of plume mass injection of this study (Fig. 4, right-hand panels) and the 90th percentile of CALIOP (Fig. 6) showed generally good agree- ment, with our estimates being slightly lower than those estimated by CALIOP.

In February (Fig. 6a), CALIOP observations in southern Europe show the majority of the plumes below $1 \mathrm{~km}$, which is the same range as in the present study (Fig. 4b). In south-east Asia, the height varies. A typical level is about $1.5 \mathrm{~km}$ over the bulk of the area (current study suggests $1-1.5 \mathrm{~km}$, see Fig. $4 \mathrm{~b}$ ) but up to $3 \mathrm{~km}$ is suggested over industrial regions of China, which is not reproduced by the current study (Fig. 4b). It is, however, unclear how such strong fires can show up in densely populated and highly cultivated and industrialised regions. Possibly, a mis-attribution of anthropogenic PM and wind-blown dust to fires can be a plausible explanation. Surprisingly, no fire plumes were recognised by CALIOP in equatorial Africa, whereas in the south their density is disproportionately large compared to that of active fires: the main fire season there is June-September, not February. These inconsistencies are probably again due to incorrect attribution of the observed plumes. The pattern in southern Africa qualitatively agrees with our results: the 90th percentile of the plumes is between $1 \mathrm{~km}$ and $2.5 \mathrm{~km}$ with downward trend towards the coast. Finally, observations in equatorial South America suggest about 1-1.5 km typical height, in agreement with the current predictions.

Comparison of the patterns for August is more homogeneous: plumes in Amazonia, southern Africa, southern Europe, eastern US and south-east Asia, are well represented in the CALIOP dataset and the patterns are less noisy. As in February, the ranges are similar to the present study, with a tendency to show somewhat higher elevations than predicted - by a few hundred metres.

The limited but systematic difference between our estimates and CALIOP observations can originate from at least three sources: (i) the uncertainties of our procedures, (ii) missing low plumes in the CALIPSO dataset, or (iii) the impact of aged plumes recorded by CALIOP together with fresh ones. Old plumes are dispersed over thicker layers, so that their top (and upper percentiles) is usually positioned higher. This effect is well seen in Africa (Fig. 6b), where the plume elevation sharply increases with distance from burning areas - towards coastlines and offshore (see also Fiedler 
et al. (2011) for estimates of the smoke export from the continent).

The impact of aged plumes made evaluation of the nighttime profiles meaningless: CALIOP did not record any significant difference compared to the daytime. In several regions, the nighttime plumes were even higher than during the day. This is not surprising: the fire emission during the day is 10-20 times stronger than during the night, so the previousday plumes recorded at night easily overshadow the fresh smoke and hide the actual position of the newly released plumes.

\subsection{Comparison of $90 \%$ map and zonal averages with AEROCOM}

We are aware of only one global, spatially resolving map of mean injection top: the one recommended for the AEROCOM (Aerosol Comparisons between Observations and Models) modelling community by Dentener et al. (2006). In that work, the authors assigned certain release profiles to the specific land-use types (see Table 4, Dentener et al., 2006) and suggested the maximum release height map (see Fig. 9 of Dentener et al., 2006). Unfortunately, it is not clear how those profiles and maximum heights were obtained.

The suggested AEROCOM maximum heights can be related to our upper percentile maps (Fig. 4), whereas the profiles of Table 4 of Dentener et al. (2006) can, to some extent, be related to the zonal average (Fig. 5). Such a comparison reveals similarities but also significant differences between the estimates.

Among the similarities, one can notice the western part of North America, where both datasets suggest quite high fires reaching $3 \mathrm{~km}$. Agreement exists also over Oceania and parts of Australia, where the height of $90 \%$ of the mass injection is close to the top height recommended for AEROCOM.

For South America the datasets show significantly different patterns: the current assessment has not registered high plumes over the eastern coast and in the south, instead reporting them in the forest regions in the middle of the continent, in agreement with CALIOP observations. The number of fires follows this trend too (Fig. 3). Such a pattern is to be expected since in densely populated coastal regions the fires are controlled more tightly than in tropical forest, whether or not they are set deliberately. As a result, the fire strength should be lower in the more densely populated regions.

Patterns over Eurasia and Australia differ strongly. The highest plumes in the AEROCOM map are over semi-desert areas of Australia and tundra in northern Eurasia, where MODIS registered just a few small fires. These regions are also characterised by a limited amount of fuel available for quick consumption and, in the case of northern Eurasia, frequent occasions of shallow ABL even during summer (Baklanov and Grisogono, 2007). Therefore, it seems unlikely to have high plumes over these regions, in agreement with our calculations.

\subsection{Diurnal and seasonal variations of the injection profiles}

Diurnal variation of the injection height is huge (Figs. 4, 5): one can practically consider two independent datasets one for daytime and one for nighttime, with transition during morning and evening.

Apart from the diurnal variations, the seasonal changes of the injection profile are also important: as our analysis showed, both FRP and ABL height follow quite similar seasonality with peaks in dry hot months. As a result, the mean height of the 90th percentile of the injection profiles shows seasonal variation of about $30-40 \%$. This result is in qualitative agreement with Val Martin et al. (2010) estimates for North America.

\subsection{Impact of inhomogeneous meteorological data}

The current study used operational meteorological data of ECMWF, which keeps developing its model and periodically updates the operational version. Since 2000, its horizontal and vertical resolutions have increased, the amount of assimilated observational information has grown manifold, several modules were updated, etc. More homogeneous would be the ERA-Interim dataset (Dee et al., 2011), which has constant resolution and a model version. However, it has several drawbacks: (i) it is still not completely homogeneous since the assimilated data vary, (ii) it has lower vertical resolution than the operational model (60 levels versus 91 levels starting from 2006). Therefore, we stick to the operational ECMWF data but used our own procedure, deriving $H_{\mathrm{ABL}}$ from the basic meteorological parameters (temperature and wind speed profiles, see Sect. 2.2.2), which was the same for all years. We also checked that $H_{\mathrm{ABL}}$ and $N_{\mathrm{FT}}$ do not have trends and break-points that can be attributed to the changes in the ECMWF model. Arguably the most suspicious moment in that respect is 2 February 2006 when the model vertical grid was changed from 61 to 91 levels, along with other modifications.

Since variations of $N_{\mathrm{FT}}$ have only minor effects on the injection height (Sofiev et al., 2012), below we present only the analysis of ABL height. Its variations between the seasons and years are illustrated via histograms calculated for each month using all terrestrial grid cells (Fig. 7).

Examples in Fig. 7 show certain variability in the $H_{\mathrm{ABL}}$ histograms, both between seasons and years. However, they do not have any clear trend and their variations cannot be related to any of the ECMWF model changes, including the above-mentioned rise of resolution. Indeed, considering for instance histograms for February, one can notice three years that have higher fractions of $H_{\mathrm{ABL}}$ from $600 \mathrm{~m}$ to $900 \mathrm{~m}$ (highlighted as thick dashed lines) with lower fractions of very thick ABLs in comparison with others. But these are the years 2001, 2002 (both 61 levels), and 2008 (91 levels), i.e. this effect is due to inter-annual variation 

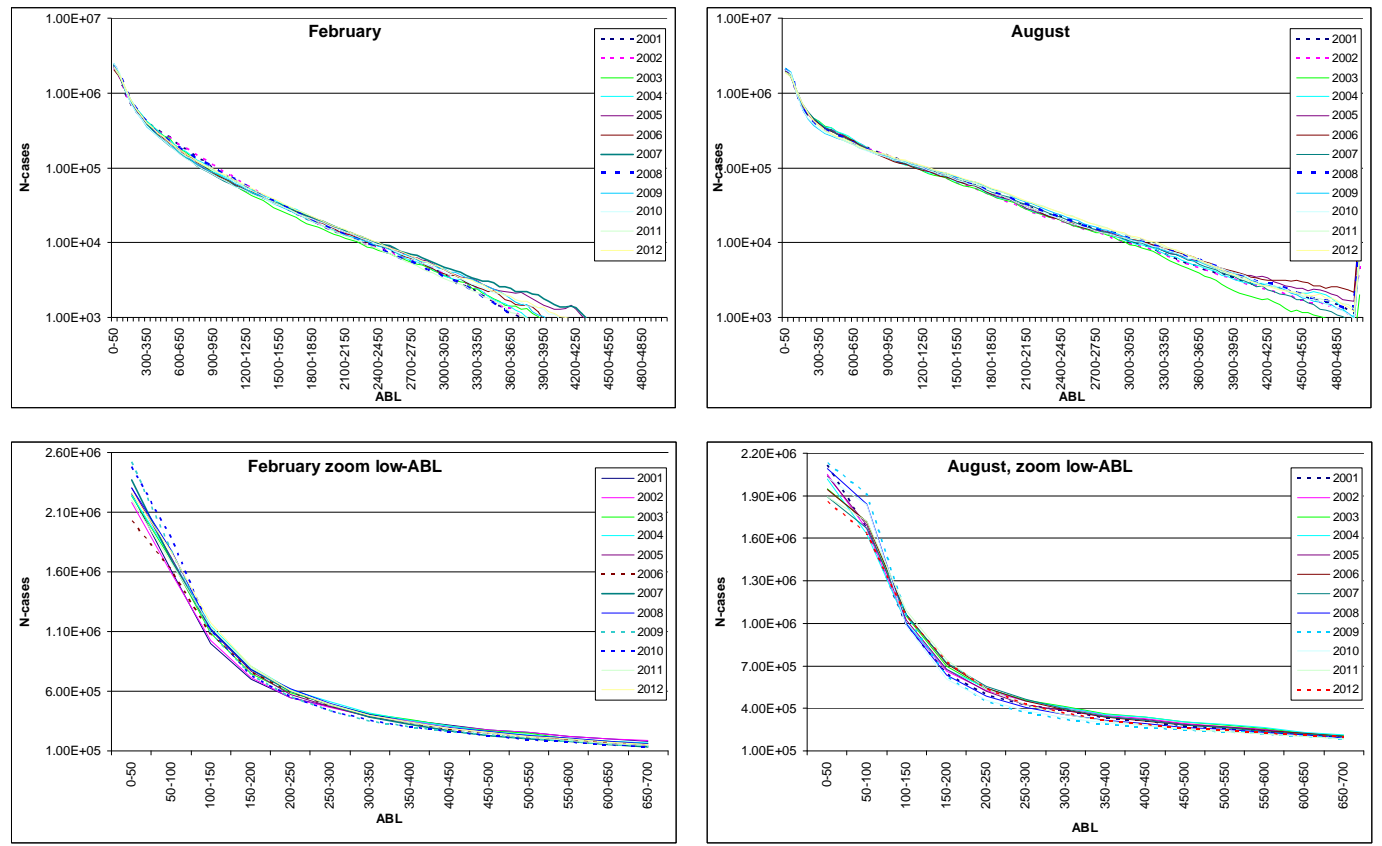

Fig. 7. Histograms of ABL over land, February (left), August (right). Lower row shows the same charts as the upper one, zoomed for low ABL heights.
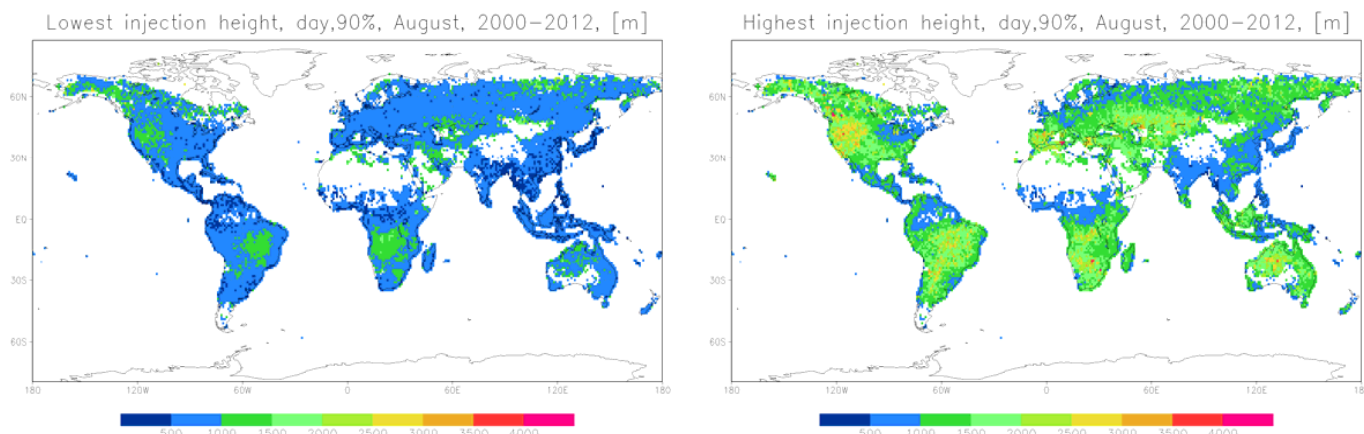

Fig. 8. Inter-annual variability of monthly profiles. Maps of lowest (left) and highest (right) monthly injection top heights for the $90 \%$ of mass, $\min / \max$ over 2000-2012. August, daytime. Unit $=[\mathrm{m}]$.

rather than systematic model changes. A similar effect is seen from the zoom over shallow ABLs: the highest fraction of $H_{\mathrm{ABL}}<150 \mathrm{~m}$ was in 2009 and 2010 , whereas the lowest one - in 2006;; all three were derived from the data with 91 vertical levels.

Histograms in August are barely distinguishable between the years, with some difference showing up only for the thickest ABLs. And again, no regular pattern or any relation to the vertical resolution change in 2006 was found. Therefore, we conclude that the meteorological input of the study does not have significant trends or break-points due to changes in the ECMWF meteorological model.

\subsection{Representativeness of the obtained profiles for specific applications}

The current profiles have been obtained from the analysis of over $12.5 \mathrm{yr}$ - from March 2000 till November 2012. These include all available to-date FRP data from MODIS and provide the best possible coverage ensuring that no fire-prone region is missing from the maps (Figs. 3, 4). Still, the number of fire events for specific months can be fewer than 10 for some grid cells (Fig. 3). For these areas the results of the current computations should be taken with care.

The dataset is a result of very strong averaging. The obtained profiles therefore represent the typical fire behaviour, and their application to extreme episodes is not justified. For such cases, explicit calculations of smoke injection from each 
fire is mandatory, possibly, with the two-step procedure suggested by Sofiev et al. (2012).

At a monthly level, representativeness of the results is better but year-to-year variability is still significant. The related uncertainty can be qualitatively illustrated by comparing the lowest and the highest positions of the 90th monthly percentile among the considered years. Such maps were compiled in Fig. 8, where each grid cell represents the lowest (panel a) and the highest (panel b) position of the 90th percentile in August among all considered years. Similar maps for all months are available together with the main dataset at http://is4fires.fmi.fi.

\section{Summary}

The presented dataset is the result of bottom-up computations of characteristic vertical profiles of smoke from wildland fires. It is obtained by processing records of active fires of MODIS instruments onboard Aqua and Terra satellites. The analysis was made for daytime and nighttime separately, covered all years available to date from MODIS (2000-2012), extended over the whole globe, and resulted in monthly 3-D maps of injected fraction of fire smoke.

The computations showed that the highest plumes reaching up to $6 \mathrm{~km}$ are characteristic for forested areas, whereas grassland fires usually emit within the lowest $2-3 \mathrm{~km}$. However, $90 \%$ of mass is emitted within $\sim 3 \mathrm{~km}$ layer, if the longterm average is considered.

Strong diurnal and seasonal variations of the injection profiles were found all over the globe. It is therefore recommended to account for these variations in practical applications.

Comparison with the independent CALIOP observations showed high similarity of the patterns. Somewhat higher altitude of the 90th percentile obtained by the lidar (few hundreds of metres) could originate from the impact of aged plumes dispersed over thick layers and recorded by lidar together with the fresh smoke from the fires.

Comparison with AEROCOM recommendations showed both similarities and differences between the injection height maps. However, in most cases the results of the current study seem to be more logical and supported by CALIOP data, especially in the areas with significant seasonal variations of the injection height.

Noticeable inter-annual variation suggests that a dynamic evaluation of emission from each specific fire, if it appears possible, would bring about more accurate estimates, especially if a limited-time regional episode is concerned. The current dataset is mostly useful for long-term global and continental studies, where an analysis of each individual fire is unfeasible.

The dataset is publicly available at http://is4fires.fmi.fi.
Acknowledgements. The study has been performed within the ESA GlobEmission and TEKES KASTU 2 projects. Support of EU FP7 PASODOBLE and PEGASOS, Academy of Finland ASTREX and Russian projects "Conducting of problem-oriented research in monitoring technologies and forecasting of atmospheric state in forest and peat fire" and "Grant to research projects implemented under the supervision of the worlds leading scientists (contract No. 11.G34.31.0078)" is kindly acknowledged. Discussions with MACC and AEROCOM fire assessment teams are highly appreciated. The MODIS, MISR and CALIOP satellite data were obtained from public online data banks of NASA. MSG SEVIRI data were archived from the ENVISAT dissemination service.

Edited by: S. Kloster

\section{References}

Baklanov, A. and Grisogono, B.: Atmospheric boudnary layers. Nature, theory, and application to environmental modelling and security, Springer, Dubrovnik, 2007.

Briggs, G. A.: Plume rise predictions, in Lectures on air pollution and environmental impact analyses, 59-111, Boston, 1975.

CALIPSO: CALIPSO Quality Statements Lidar Level 3 Aerosol Profile Monthly Products Version Release: 1.00, 2011.

Davison, P. S.: Estimating the direct radiative forcing due to haze from the 1997 forest fires in Indonesia, J. Geophys. Res., 109, 1-12, doi:10.1029/2003JD004264, 2004.

Dee, D. P., Uppala, S. M., Simmons, A. J., Berrisford, P., Poli, P., Kobayashi, S., Andrae, U., Balmaseda, M. A., Balsamo, G., Bauer, P., Bechtold, P., Beljaars, A. C. M., van de Berg, L., Bidlot, J., Bormann, N., Delsol, C., Dragani, R., Fuentes, M., Geer, A. J., Haimberger, L., Healy, S. B., Hersbach, H., Hólm, E. V., Isaksen, L., Kållberg, P., Köhler, M., Matricardi, M., McNally, A. P., Monge-Sanz, B., M. Morcrette, J.-J., Park, B.-K., Peubey, C., de Rosnay, P., Tavolato, C., Thépaut, J.-N., and Vitart, F.: The ERA-Interim reanalysis: configuration and performance of the data assimilation system, Q. J. Roy. Meteorol. Soc., 137, 553597, doi:10.1002/qj.828, 2011.

Dentener, F., Kinne, S., Bond, T., Boucher, O., Cofala, J., Generoso, S., Ginoux, P., Gong, S., Hoelzemann, J. J., Ito, A., Marelli, L., Penner, J. E., Putaud, J.-P., Textor, C., Schulz, M., van der Werf, G. R., and Wilson, J.: Emissions of primary aerosol and precursor gases in the years 2000 and 1750 prescribed data-sets for AeroCom, Atmos. Chem. Phys., 6, 4321-4344, doi:10.5194/acp-64321-2006, 2006.

Dirksen, R. J., Folkert Boersma, K., de Laat, J., Stammes, P., van der Werf, G. R., Val Martin, M., and Kelder, H. M.: An aerosol boomerang: Rapid around-the-world transport of smoke from the December 2006 Australian forest fires observed from space, J. Geophys. Res., 114, 1-15, doi:10.1029/2009JD012360, 2009.

Fiedler, V., Arnold, F., Ludmann, S., Minikin, A., Hamburger, T., Pirjola, L., Dörnbrack, A., and Schlager, H.: African biomass burning plumes over the Atlantic: aircraft based measurements and implications for $\mathrm{H}_{2} \mathrm{SO}_{4}$ and $\mathrm{HNO}_{3}$ mediated smoke particle activation, Atmos. Chem. Phys., 11, 3211-3225, doi:10.5194/acp-11-3211-2011, 2011.

Fisher, B. E. A.,. Erbrink, J. J., Finardi, S., Jeannet, P., Joffre, S., Morselli, M. G., Pechinger, U., Seibert, P., and Thomson, D. J.: COST Action 710 - Final report. Harmonisation of the pre- 
processing of meteorological data for atmospheric dispersion models, edited by: Fisher, B. E. A., Erbrink, J. J., Finardi, S., Jeannet, P., Joffre, S., Morselli, M. G., Pechinger, U., Seibert, P., and Thomson, D.: Office for Official Publications of the European Communities, Luxembourg, available from: http://www2. dmu.dk/atmosphericenvironment/cost/FinalRep.htm, 1998.

Forster, C. Wandinger, U. Wotawa, G., James, P., Mattis, I, Althausen, D., Simmonds, P., O'Doherty, S., Jennings, S. G., Kleefeld, C., Schneider, J., Trickl, T., Kreipl, S., Jäger, H., and Stohl, A.: Transport of boreal forest fire emissions from Canada to Europe, J. Geophys. Res., 106, 22887-22906, doi:10.1029/2001JD900115, 2001.

Freeborn, P. H., Wooster, M. J., Hao, W. M., Ryan, C. A., Nordgren, B. L., Baker, S. P., and Ichoku, C.: Relationships between energy release, fuel mass loss, and trace gas and aerosol emissions during laboratory biomass fires, J. Geophys. Res., 113, 117, doi:10.1029/2007JD008679, 2008.

Freitas, S. R., Longo, K. M., Chatfield, R., Latham, D., Silva Dias, M. A. F., Andreae, M. O., Prins, E., Santos, J. C., Gielow, R., and Carvalho Jr., J. A.: Including the sub-grid scale plume rise of vegetation fires in low resolution atmospheric transport models, Atmos. Chem. Phys., 7, 3385-3398, doi:10.5194/acp-7-3385-2007, 2007.

Fromm, M., Jerome, A., Hoppel, K., Hornstein, J., Bevilacqua, R., Shettle, E., Servranckx, R., Zhanqing, L., and Stocks, B.: Observations of boreal forest fire smoke in the stratosphere by POAM III, SAGE II, and lidar in 1998, Geophys. Res. Lett., 27, 14071410, doi:10.1029/1999GL011200, 2000.

Giglio, L.: Characterization of the tropical diurnal fire cycle using VIRS and MODIS observations, Remote Sens. Environ., 108, 407-421, doi:10.1016/j.rse.2006.11.018, 2007.

Ichoku, C., Giglio, L., Wooster, M. J., and Remer, L. A.: Global characterization of biomass-burning patterns using satellite measurements of fire radiative energy, Remote Sens. Environ., 112, 2950-2962, doi:10.1016/j.rse.2008.02.009, 2008a.

Ichoku, C., Giglio, L., Wooster, M. J., and Remer, L. A.: Global characterization of biomass-burning patterns using satellite measurements of fire radiative energy, Remote Sens. Environ., 112, 2950-2962, doi:10.1016/j.rse.2008.02.009, 2008b.

Justice, C. O., Giglio, L., Korontzi, S., Owens, J., Morisette, J. T., Roy, D., Descloitres, J., Alleaume, S., Petitcolin, F., and Kaufman, Y.: The MODIS fire products, Remote Sens. Environ., 83, 244-262, 2002.

Kahn, R. A., Chen, Y., Nelson, D. L., Leung, F.-Y., Li, Q., Diner, D. J., and Logan, J. A.: Wildfire smoke injection heights: Two perspectives from space, Geophys. Res. Lett., 35, 4-7, doi:10.1029/2007GL032165, 2008.

Kaiser, J. W., Wooster, M. J., Roberts, G., Schultz, M. G., Van Der Werf, G., and Benedetti, A.: SEVIRI Fire Radiative Power and the MACC Atmospheric Services, in EUMETSAT Meteorological Satellite Conf., ISBN 978-92-9110-086-6, ISSN 1011-3932, 2005-2009, EUMETSAT, Darmstadt, Germany, 2009.

Kaiser, J. W., Heil, A., Andreae, M. O., Benedetti, A., Chubarova, N., Jones, L., Morcrette, J.-J., Razinger, M., Schultz, M. G., Suttie, M., and van der Werf, G. R.: Biomass burning emissions estimated with a global fire assimilation system based on observed fire radiative power, Biogeosciences, 9, 527-554, doi:10.5194/bg-9-527-2012, 2012.
Kaufman, I., Steele, M., Cummings, D. L., and Jaramillo, V. J.: Biomass dynamics associated with deforestation, fire, and, conversion to cattle pasture in a Mexican tropical dry forest, Forest Ecol. Manage., 176, 1-12, 2003.

Kaufman, Y. J., Justice, C. O., Flynn, L. P., Kendall, J. D., Prins, E. M., Giglio, L., Ward, D. E., Menzel, W. P., and Setzer, A. W. (1998), Potential global fire monitoring from EOS-MODIS, J. Geophys. Res.-Atmos., 103, 32215-21238, 1998.

Kouznetsov, R., Wood, C., Soares, J., Sofiev, M., Karppinen, A., and Fortelius, C.: Sodar verification for boundary-layer height diagnostics in meteorological models, in Proc. 16-th Int. Symp. for the Advancement of Boundary Layer Remote Sensing (P017, 1-4). Boulder, CO., PO1-7, 1-4, Boulder, CO, 2012.

Labonne, M., Bréon, F.-M., and Chevallier, F.: Injection height of biomass burning aerosols as seen from a spaceborne lidar, Geophys. Res. Lett., 34, 1-5, doi:10.1029/2007GL029311, 2007.

Lavoué, D., Liousse, C., Cachier, H., Stocks, B. J., and Goldammer, J. G.: Modeling of carbonaceous particles emitted by boreal and temperate wildfires at northern latitudes, J. Geophys. Res., 105(D22), 26871-26890, doi:10.1029/2000JD900180, 2000.

Liousse, C., Penner, J. E., Chuang, C., Walton, J. J., Eddleman, H., and Cachier, H.: A global three-dimensional model study of carbonaceous aerosols, J. Geophys. Res., 101, 19411-19432, doi:10.1029/95JD03426, 1996.

Luderer, G., Trentmann, J., Winterrath, T., Textor, C., Herzog, M., Graf, H. F., and Andreae, M. O.: Modeling of biomass smoke injection into the lower stratosphere by a large forest fire (Part II): sensitivity studies, Atmos. Chem. Phys., 6, 5261-5277, doi:10.5194/acp-6-5261-2006, 2006.

Mazzoni, D., Logan, J. A., Diner, D., Kahn, R. A., Tong, L., and Li, Q.: A data-mining approach to associating MISR smoke plume heights with MODIS fire measurements, Remote Sens. Environ., 107, 138-148, 2007.

Nelson, D., Lawshe, C., Diner, D., and Kahn, R.: MISR Plume Height Project, Data Quality Statement and Error Analysis, 3, available from: http://www-misr.jpl.nasa.gov/getData/ accessData/MisrMinxPlumes/qualityStatement/, 2008.

Omar, A. H., Winkar, D. M., Kittaka, C., Vaughan, M. A., Liu,Z., Hu, Y., Trepte, C. R., Rogers, R. R., Ferrare, R. A., Lee, K.-P., Kuehn, R. E., Hostetler, C. A.: The CALIPSO Automated Aerosol Classification and Lidar Ratio Selection Algorithm, J. Atmos. Ocean. Tech., 26, 1994-2014, doi:10.1175/2009JTECHA1231.1, 2009.

Raffuse, S. M., Craig, K. J., Larkin, N. K., Strand, T. T., Sullivan, D. C., Wheeler, N. J. M., and Solomon, R.: An Evaluation of Modeled Plume Injection Height with SatelliteDerived Observed Plume Height, Atmosphere, 3, 103-123, doi:10.3390/atmos3010103, 2012.

Rio, C., Hourdin, F., and Chédin, A.: Numerical simulation of tropospheric injection of biomass burning products by pyro-thermal plumes, Atmos. Chem. Phys., 10, 3463-3478, doi:10.5194/acp10-3463-2010, 2010.

Roberts, G. J. and Wooster, M. J.: Fire Detection and Fire Characterization Over Africa Using Meteosat SEVIRI, IEEE Transactions on Geoscience and Remote Sensing, 46, 1200-1218, doi:10.1109/TGRS.2008.915751, 2008.

Roberts, G., Wooster, M. J., and Lagoudakis, E.: Annual and diurnal african biomass burning temporal dynamics, Biogeosciences, 6 , 849-866, doi:10.5194/bg-6-849-2009, 2009. 
Sofiev, M., Siljamo, P., Valkama, I., Ilvonen, M., and Kukkonen, J.: A dispersion modelling system SILAM and its evaluation against ETEX data, Atmos. Environ., 40, 674-685, doi:10.1016/j.atmosenv.2005.09.069, 2006.

Sofiev, M., Vankevich, R., Lotjonen, M., Prank, M., Petukhov, V., Ermakova, T., Koskinen, J., and Kukkonen, J.: An operational system for the assimilation of the satellite information on wildland fires for the needs of air quality modelling and forecasting, Atmos. Chem. Phys., 9, 6833-6847, doi:10.5194/acp-9-68332009, 2009.

Sofiev, M., Ermakova, T., and Vankevich, R.: Evaluation of the smoke-injection height from wild-land fires using remote-sensing data, Atmos. Chem. Phys., 12, 1995-2006, doi:10.5194/acp-12-1995-2012, 2012.

Stein, A. F., Rolph, G. D., Draxler, R. R., Stunder, B., and Ruminski, M.: Verification of the NOAA Smoke Forecasting System: Model Sensitivity to the Injection Height, Weather Forecast., 24, 379-394, doi:10.1175/2008WAF2222166.1, 2009.

Sukhinin, A. I., Conard, S. G., McRae, D. J., Ivanova, G. A., Tsvetkov, P. A., Bychkov, V. A., and Slinkina, O. A.: Remote Sensing of Fire Intensity and Burn Severity in Forests of Central Siberia, in Contemporary Problems of Earth Remote Sensing from Space, Space Research Institute RAS, Mscow, available from: http://www.iki.rssi.ru/earth/ppt2005/sukhinin.pdf, 2005.

Tosca, M. G., Randerson, J. T., Zender, C. S., Nelson, D. L., Diner, D. J., and Logan, J. A.: Dynamics of fire plumes and smoke clouds associated with peat and deforestation fires in Indonesia, J. Geophys. Res., 116, D08207, doi:10.1029/2010JD015148, 2011.

Val Martin, M., Logan, J. A., Kahn, R. A., Leung, F.-Y., Nelson, D. L., and Diner, D. J.: Smoke injection heights from fires in North America: analysis of 5 years of satellite observations, Atmos. Chem. Phys., 10, 1491-1510, doi:10.5194/acp-10-14912010, 2010. van der Werf, G. R., Randerson, J. T., Giglio, L., Collatz, G. J., Kasibhatla, P. S., and Arellano Jr., A. F.: Interannual variability in global biomass burning emissions from 1997 to 2004, Atmos. Chem. Phys., 6, 3423-3441, doi:10.5194/acp-6-3423-2006, 2006.

van der Werf, G. R., Randerson, J. T., Giglio, L., Collatz, G. J., Mu, M., Kasibhatla, P. S., Morton, D. C., DeFries, R. S., Jin, Y., and van Leeuwen, T. T.: Global fire emissions and the contribution of deforestation, savanna, forest, agricultural, and peat fires (19972009), Atmos. Chem. Phys., 10, 11707-11735, doi:10.5194/acp10-11707-2010, 2010.

Vaughan, M. A., Powell, K. A., Kuehn, R. E., Young, S. A., Winker, D. M., Hostetler, C. A., Hunt, W. H., Liu, Z., McGill, M. J., and Getzewich, B. J.: Fully Automated Detection of Cloud and Aerosol Layers in the CALIPSO Lidar Measurements, J. Atmos. Ocean. Tech., 26, 2034-2050, doi:10.1175/2009JTECHA1228.1, 2009.

Vermote, E., Ellicott, E., Dubovik, O., Lapyonok, T., Chin, M., Giglio, L., and Roberts, G. J.: An approach to estimate global biomass burning emissions of organic and black carbon from MODIS fire radiative power, J. Geophys. Res., 114, 1-22, doi:10.1029/2008JD011188, 2009.

Wang, J., Christopher, S. A., Nair, U. S., Reid, J. S., Prins, E. M., Szykman, J., and Hand, J. L.: Mesoscale modeling of Central American smoke transport to the United States: 1. "Top-down" assessment of emission strength and diurnal variation impacts, J. Geophys. Res., 111, 1-21, doi:10.1029/2005JD006416, 2006.

Westphal, L. and Toon, O. B.: Simulations of Microphysical, Radiative, and Dynamical Processes in a Continental-Scale Forest Fire Smoke Plume, J. Geophys. Res., 96, 22379-22400, doi:10.1029/91JD01956, 1991.

Wooster, M. J., Roberts, G., Perry, G. L. W., and Kaufman, Y. J.: Retrieval of biomass combustion rates and totals from fire radiative power observations: FRP derivation and calibration relationships between biomass consumption and fire radiative energy release, J. Geophys. Res., 110, D24311, doi:10.1029/2005JD006318, 2005. 